\title{
U-PB AND LU-HF ISOTOPE, AGE, ANDTRACE ELEMENT DATA FROM ZIRCON SEPARATES FROM THE TANACROSS D-1, AND PARTS OF D-2, C-1, AND C-2 QUADRANGLES
}

Erin Todd, Alicja Wypych, and Andrew Kylander-Clark

Raw Data File 2019-5

2019

State of Alaska

Department of Natural Resources

Division of Geological \& Geophysical Surveys

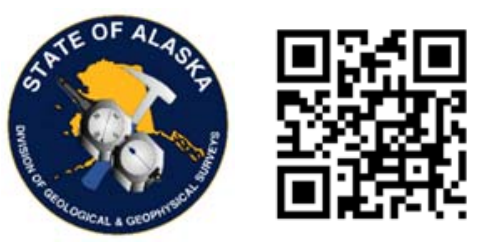


STATE OF ALASKA

Michael J. Dunleavy, Governor

\section{DEPARTMENT OF NATURAL RESOURCES}

Corri A. Feige, Commissioner

\section{DIVISION OF GEOLOGICAL \& GEOPHYSICAL SURVEYS}

Steve Masterman, State Geologist \& Director

Publications produced by the Division of Geological \& Geophysical Surveys are available to download from the DGGS website (dggs.alaska.gov). Publications on hard-copy or digital media can be examined or purchased in the Fairbanks office:

\section{Alaska Division of Geological \& Geophysical Surveys (DGGS)}

3354 College Road | Fairbanks, Alaska 99709-3707

Phone: 907.451.5010 | Fax 907.451.5050

dggspubs@alaska.gov $\mid$ dggs.alaska.gov

\section{DGGS publications are also available at:}

Alaska State Library, Historical

Collections \& Talking Book Center

395 Whittier Street

Juneau, Alaska 99801

Alaska Resource Library and

Information Services (ARLIS)

3150 C Street, Suite 100

Anchorage, Alaska 99503

\section{Suggested citation:}

Todd, Erin, Wypych, Alicja, and Kylander-Clark, Andrew, 2019, U-Pb and Lu-Hf isotope, age, and trace element data from zircon separates from northeastern Tanacross, Tanacross D-1, and parts of D-2, C-1, and C-2 quadrangles: Alaska Division of Geological \& Geophysical Surveys Raw Data File 2019-5, 10 p. http://doi.org/10.14509/30198
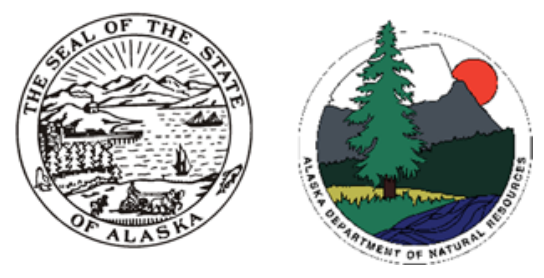


\section{U-PB AND LU-HF ISOTOPE, AGE, AND TRACE ELEMENT DATA FROM ZIRCON SEPARATES FROM THE TANACROSS D-1, AND PARTS OF THE D-2, C-1, AND C-2 QUADRANGLES}

Erin Todd ${ }^{1}$, Alicja Wypych², and Andrew Kylander-Clark ${ }^{3}$

\section{INTRODUCTION}

This Alaska Division of Geological \& Geophysical Surveys (DGGS) Raw Data File presents U-Pb geochronology, Lu-Hf isotopic compositions, and trace-element composition of zircons from six metaigneous and igneous rocks sampled during investigations by DGGS geologists in the northeastern Tanacross quadrangle. The purpose of the Lu-Hf and U-Pb isotopic study is to better understand the Devonian-toMississippian and Mesozoic-to-early Paleogene episodes of magmatic and tectonic evolution of the YukonTanana Uplands and the significance of magmatism to the formation of metallic mineral deposits.

The DGGS Northeast Tanacross project is a part of multi-year effort to better understand the mineral potential of the Yukon-Tanana Uplands region in collaboration with the U.S. Geological Survey. This area is characterized by the presence of two Devonian to Mississippian metamorphic assemblages- the Lake George and Fortymile assemblages (Dusel-Bacon and others, 2006; Foster, 1970). Both assemblages are composed of metasedimentary rocks intruded by orthogneiss and amphibolite. The Lake George assemblage also contains extensive potassium feldspar augen gneiss. Following metamorphism, both assemblages were intruded by mid- to Late-Cretaceous volcanic and plutonic rocks (Naibert and others, 2018) with high potential for gold, but also silver, zinc, copper, and lead mineralization.

Products included in this data release are: A summary of sample collection methods, the laboratory report, analytical data tables, and associated metadata.

\section{SAMPLE COLLECTION TECHNIQUES}

DGGS field geologists collected fresh, unweathered samples from bedrock outcrops in 2017. Sample locations (see accompanying digital data download files) were obtained using Trimble Juno T41/5 WAASenabled GPS devices running ArcGIS for Windows Mobile. WAAS-enabled GPS devices have a reported error of about $1 \mathrm{~m}$. Data were merged into an ArcGIS geodatabase. Samples for geochronology analyses were selected based on examination of bulk samples under a binocular microscope and thin section petrography to minimize the potential for analyzing altered mineral phases.

\footnotetext{
${ }^{1}$ U.S. Geological Survey, Alaska Science Center, 4210 University Dr., Anchorage, AK 99508-4626

${ }^{2}$ Alaska Division of Geological \& Geophysical Surveys, 3354 College Road, Fairbanks, AK 99709-3707

${ }^{3}$ U.C. Santa Barbara, Santa Barbara, CA 93106; kylander@geol.ucsb.edu
} 


\section{ANALYTICAL METHODS}

Zircon grains were extracted by Zirchron LLC (Tucson, AZ). Each sample was individually unpacked and pressure washed with water to remove any debris and/or foreign material. Sample rock fragments were placed in the sample chamber of an Electro Pulse Disaggregator (EPD, Marx generator), then electrical pulses were applied at $1 \mathrm{~Hz}$ repetition and discharges of $\sim 250 \mathrm{kV}$ for 15 minutes. The sample materials passing through a $500 \mu \mathrm{m}$ stainless steel mesh sieve were collected in a disposable plastic bag. Coarser material remaining in the sample chamber was collected, dried, and if necessary, reduced by traditional methods (rock crusher and disk pulverizer). The collected material $(<500 \mu \mathrm{m})$ was then sieved a second time through 350 $\mu \mathrm{m}$ and $25 \mu \mathrm{m}$ nylon disposable mesh sieves. Material smaller than $25 \mu \mathrm{m}$ was discarded. Material sized between $350 \mu \mathrm{m}$ and $25 \mu \mathrm{m}$ was then processed by following traditional methods using the Wilfley water table, Frantz paramagnetic separator, and two-step $\left(3.00 \mathrm{~g} / \mathrm{cm}^{3}\right.$ and $\left.3.32 \mathrm{~g} / \mathrm{cm}^{3}\right)$ heavy liquid methylene iodide separations.

$\mathrm{Hf}$ isotopes, $\mathrm{U}-\mathrm{Pb}$ ratios, and trace-element compositions for all zircons were measured simultaneously at the University of California, Santa Barbara (UCSB) by laser ablation split-stream (LASS; Kylander-Clark and others, 2013) in May 2018 using the Photon Machines Analyte 193-nm excimer laser, ablating sample material using spot sizes of $65 \mu \mathrm{m}$ or $50 \mu \mathrm{m}$, depending on grain size of sample zircons. Spot sizes and laserrun conditions for each sample are given in the summary analytical table. The laser was fired twice to remove surface contamination (primarily common $\mathrm{Pb}$ ), and this material was allowed to wash out for 40 seconds. $\mathrm{Hf}$ (and $\mathrm{Lu}$ ) isotopes were measured on the $\mathrm{Nu}$ Instruments $\mathrm{Nu}$ Plasma 3D (HR-MC-ICP-MS). U-Pb isotope ratios and trace-element compositions were measured on an Agilent 7700x quadrupole ICP-MS. All raw mass spectrometry data acquired during laser ablation were processed using Iolite (version 2.5; Paton and others, 2010, 2011).

Analyses of unknown samples during the session were bracketed by analyses of the zircon reference materials (RM) 91500 and Mud Tank; 91500 was used as the primary RM for U-Pb geochronology and traceelement analyses. Mud Tank and the 91500 zircons $\left({ }^{176} \mathrm{Hf} /{ }^{177} \mathrm{Hf}=0.282490 \pm 12, \mathrm{MSWD}=0.75 ; \mathrm{n}=58\right.$ ) were used as the primary RM for Hf isotopes (no correction was applied because measured values were in agreement with accepted ratios; ${ }^{176} \mathrm{Hf} /{ }^{177} \mathrm{Hf}=0.282507 \pm 6$; Woodhead and Hergt, 2005). For some later runs in the session, polished surfaces on the Mud Tank grain mount were used up, so 91500 was considered to be the primary $\mathrm{Hf}$ standard $\left({ }^{176} \mathrm{Hf} /{ }^{177} \mathrm{Hf}=0.282308 \pm 6, \mathrm{MSWD}=0.53 ; \mathrm{n}=424\right)$, which was also in agreement with accepted ratios $\left({ }^{176} \mathrm{Hf} /{ }^{177} \mathrm{Hf}=0.282306 \pm 8\right.$; Woodhead and Hergt, 2005). Additional zircon RM GJ-1 (U$\mathrm{Pb}$ age $\left.=603.7 \pm 1.2, \mathrm{MSWD}=0.86 ;{ }^{176} \mathrm{Hf} /{ }^{177} \mathrm{Hf}=0.282013 \pm 9, \mathrm{MSWD}=0.60 ; \mathrm{n}=426\right)$, Plesovice $(\mathrm{U}-\mathrm{Pb}$ age $\left.=338.6 \pm 0.9, \mathrm{MSWD}=0.98 ;{ }^{176 \mathrm{Hf} /}{ }^{177} \mathrm{Hf}=0.282490 \pm 7, \mathrm{MSWD}=0.83 ; \mathrm{n}=114\right)$, and Temora2 $(\mathrm{U}-\mathrm{Pb}$ age $=$ $421.3 \pm 1.2, \mathrm{MSWD}=1.03 ;{ }^{176} \mathrm{Hf} /{ }^{177} \mathrm{Hf}=0.282668 \pm 9, \mathrm{MSWD}=1.02 ; \mathrm{n}=113$ ) were included as secondary standards to monitor reproducibility. Reported RM weighted means and uncertainty are for all spot sizes (65um and 50um); uncertainty $(2 \sigma)$ for ages and Hf isotopes analyzed at $50 \mu \mathrm{m}$ is generally less than or equal to two times the 2-sigma values reported for all spot sizes given above. Two-sigma analytical uncertainties associated with $\mathrm{U}-\mathrm{Pb}$ ages reported here are better than the approximately 2 percent long-term empirical scatter of ages measured at the UCSB laboratory. 
All spot analyses are shown in the detail table. Grains contributing to the youngest "main" population of a sample (that is, those that are most likely contemporaneous with the crystallization of the host rock) are distinguished from "inherited" grains that likely represent xenocrysts from an older igneous or metamorphic zircon-forming event. Calculated weighted-mean and uncertainty $(2 \sigma)$ for $\mathrm{U} / \mathrm{Pb}$ and Hf isotopes, determined using Isoplot 4.15 (Ludwig, 2002; revised 2012), and median trace element compositions are shown in table 1 and the summary table. The summary table shows only the interpolated values for the "main" population. Representative "main" or "inheritance" values in table 1 are only shown for populations with $\geq 2$ grains, with an exception for one sample (17MLW028) where zircon yield was extremely low (see "Discussion" below). Grains with discordant ages (that is, disagreement between ${ }^{206} \mathrm{~Pb} /{ }^{238} \mathrm{U}$ - and ${ }^{207} \mathrm{~Pb} /{ }^{235} \mathrm{U}$-calculated ages of $<0.80$ or $>1.05$; tolerances adjusted to $<0.70$ and $>1.10$ for smallest sample population-17MLW028) were not used to calculate weighted mean ages, hafnium isotope ratios, and representative trace-element concentration medians. Trace element medians also exclude zircon grains with anomalous trace-element concentrations where inclusions were suspected to impart non-zircon signal (for example, apatite, ilmenite) on integration of measured trace elements.

Hafnium isotope epsilon ( $(\mathrm{Hf})$ values and age-corrected isotope values were calculated assuming chondritic ${ }^{176} \mathrm{Hf} /{ }^{177} \mathrm{Hf}$ and ${ }^{176} \mathrm{Lu} /{ }^{177} \mathrm{Hf}$ ratios of 0.282772 and 0.0332 (Blichert-Toft and Albarède, 1997) and a lutetium-176 decay constant of $1.86 \times 10^{-11}$ (Scherer and others, 2001). Model ages (TDM $\mathrm{Hf}_{\mathrm{Hf}}$ ), in billions of years, were calculated assuming present-day depleted mantle ${ }^{176} \mathrm{Lu} /{ }^{177} \mathrm{Hf}$ and ${ }^{176} \mathrm{Hf} /{ }^{177} \mathrm{Hf}$ values of 0.0384 and 0.28325 (Griffin and others, 2000).

Equilibrium crystallization temperatures $\left({ }^{\circ} \mathrm{C}\right)$ for zircon were calculated using the Ti-in-zircon thermometer, after Ferry and Watson (2007), assuming activity of $\mathrm{SiO}_{2}$ and $\mathrm{TiO}_{2}\left(\alpha \mathrm{SiO}_{2}\right.$ and $\left.\alpha \mathrm{TiO}_{2}\right)$ of 0.7 .

\section{SAMPLE DESCRIPTIONS}

Samples analyzed included two deformed rocks from the Lake George assemblage (17AW017 and 17JEA001) and four undeformed igneous samples, which consisted of plutonic rocks intruding the Lake George assemblage (17AW009 and 17ET057), and volcanic rocks overlying both the Lake George and Fortymile assemblages (17MLW060 and 17MLW028, respectively).

\section{AW017}

Lake George augen orthogneiss; white to gray with black specks or smears, weathers orange; foliated, gneissic, grain size: 2 to $70 \mathrm{~mm}$; mineral assemblage: feldspar augen 60 percent, interstitial feldspar (5 percent), interstitial quartz (15 percent), biotite (15 percent) and white mica ( 5 percent). The feldspar augen are very large, some are significantly stretched, and some are rotated, preserving the crystal shape. The matrix is comprised of fine-grained quartz and feldspar, parted by biotite and white mica. Trace weathering.

\section{JEA001}

Lake George orthogneiss; gray where biotite-rich; white where quartz-rich; slightly reddish where partially weathered; foliated, blocky, grain size: 1 to $3 \mathrm{~mm}$; mineral assemblage: quartz (up to 60 percent), 
plagioclase (20 percent), microcline (10 percent), biotite clots (5-20 percent), muscovite (5 percent), accessory disseminated garnet, chlorite, opaque minerals and zircon. Anhedral quartz porphyroblasts are up to $2 \mathrm{~mm}$ long, with undulatory extinction. Feldspars are recrystallized, plagioclase is less than 1-mm-long, with polysynthetic twinning and common sericite inclusions, and anhedral microcline has clear microcline twinning. Subhedral biotite and muscovite are up to $2 \mathrm{~mm}$ long. Accessory chlorite with abnormal interference colors is no larger than $0.5 \mathrm{~mm}$; opaque minerals, up to $0.5 \mathrm{~mm}$ long, interstitial, but strongly associated with biotite; and very small crystals of zircon, often as inclusions with radiation halos in biotite. The sample has strong foliation defined by thin, less than $0.5-\mathrm{mm}$-thick layers of mica. Parts of the gneiss are more felsic with little to no biotite - compositionally segregated.

\section{AW009}

Taurus feldspar porphyry; pale gray to creamy, weathering rusty; mineral assemblage: phenocrysts of feldspar (10 percent), with recrystallized groundmass of quartz + feldspar + sericite + chlorite. Feldspar phenocrysts are up to 90 percent sericitized and about $5 \mathrm{~mm}$ long. The rock is cut by thin veins of quartz and opaque minerals (pyrite and molybdenite), and it looks to be potassium altered. The pluton is nonmagnetic.

\section{ET057}

Pika diorite; light gray; massive, diabasic, grain size: 0.5 to $2 \mathrm{~mm}$; mineral assemblage: plagioclase (85 percent), pyroxene (7 percent), biotite ( 3 percent), and magnetite (5 percent).

\section{MLW060}

Andesite near the Pika prospect; medium gray groundmass with black and white spots, weathers orange tan. Weathering is fracture-controlled. Porphyritic, grain size: 0.01 to $7 \mathrm{~mm}$; mineral assemblage: albite lath (10 percent), hornblende (5 percent), quartz (1 percent), and biotite ( $<1$ percent). Large crystalline hornblende $(<8 \mathrm{~mm})$ and partially clay-altered plagioclase laths (up to $2 \mathrm{~cm}$ ) in gray groundmass. Albite phenocrysts are subhedral, up to $5 \mathrm{~mm}$ long, with polysynthetic twinning, some sericitization, and rounded, altered edges; euhedral hornblende phenocrysts average 1-mm long up to 3-mm long, with inclusions of opaque minerals and possibly quartz; quartz phenocrysts are rare, subhedral, 2-mm long, rounded and dissolved on the edges; rare medium-grained subhedral biotite is elongated, often rounded on the edges. Opaque minerals are disseminated, about $0.1 \mathrm{~mm}$, either pyrite or magnetite (or both). The groundmass is recrystallized to a mixture of fine-grained feldspar \pm quartz and opaque minerals.

\section{MLW028}

Andesite near VABM Lode; medium to dark gray with a green cast, weathers nutmeg brown. Weathering is fracture-controlled. Porphyritic, grain size: 0.01 to $2 \mathrm{~mm}$; mineral assemblage: feldspar lath (10 percent), plagioclase (5 percent), mafic (1 percent) and accessory opaque minerals. Euhedral phenocrysts of albite or sanidine are up to $2 \mathrm{~mm}$, with rare single twin preserved. Crystals are highly altered to sericite (up to 90 percent alteration) and often have undulatory extinction. Plagioclase phenocrysts are smaller (up to $1 \mathrm{~mm}$ ), euhedral, highly altered to sericite, with polysynthetic twinning. Mafic minerals are no larger than $1 \mathrm{~mm}$, 
averaging $0.5 \mathrm{~mm}$, fully replaced by a mixture of chlorite and calcite, and are interpreted to have been hornblende based on shape. The groundmass of the sample is fully recrystallized to a mixture of very finegrained feldspar and sericite, with common opaque minerals, probably magnetite. A lithic fragment of equigranular, altered sericite and feldspar mixture and a xenolith of quartzite with about 5 percent calcite were also observed in thin section.

\section{DISCUSSION}

A summary of all $\mathrm{U}-\mathrm{Pb}$ ages, Lu-Hf isotopic data, and trace element analyses is included in the accompanying data distribution, with uncertainty for all ages, isotope ratios, and trace-element concentrations reported at the $2 \sigma$ level. Trace element data and $\mathrm{U} / \mathrm{Pb}$ age concordance were used to assess whether ablated material within the analyzed crystal was homogeneous or hosted compositional heterogeneities (that is, mineral or melt nano-inclusions). Inclusions were not presumed to have significantly affected Hf isotope compositions because of the extremely high $\mathrm{D}_{\text {ziron/melt }}$ for $\mathrm{Hf}$.

A sample collected from Lake George assemblage augen gneiss (17AW017) yielded an Early Mississippian age and a sample of Lake George orthogneiss (17JEA001) yielded a Devonian age. Zircons from the main populations of both samples have strong continental $\mathrm{Hf}$ isotope affinity $\left(\varepsilon \mathrm{Hf}_{(\mathrm{T})}<-26\right)$ and both samples have significant Proterozoic inheritance.

All of the igneous samples yielded Late Cretaceous youngest-zircon ages, clarifying previous uncertainty about whether the most recent local magmatic activity was dominantly Paleocene or Cretaceous (Foster, 1970; Wilson and others, 2015). Zircon populations from all igneous samples contained at least some inheritance. Each of the two samples from plutonic rock intruding Lake George assemblage (17AW009 and 17ET057) contained both concordant Devonian and (minor) Proterozoic grains, indicating some entrainment of the basement they intruded. Additionally, 17AW009 includes early-middle Mesozoic zircon grains, suggesting a wider, more easterly extent of intrusive magmatism of this age (for example, Taylor Mountain batholith: Foster, 1970; Dusel-Bacon and others, 2015) than was previously known from geologic mapping.

The andesite sample near the Pika prospect (17MLW060), emplaced on Lake George assemblage basement contains a single Carboniferous grain. The andesite sample emplaced on Fortymile assemblage basement (17MLW028), near the VABM Lode, yielded sparse zircon grains that were mostly Permian and Devonian, each having continental Hf isotopic affinity. These are all interpreted to be inherited, and not representative of the crystallization age of the andesite. The crystallization age of this andesite could be Late Cretaceous, represented by one Late Cretaceous zircon grain with radiogenic $\varepsilon \mathrm{Hf}_{(\mathrm{T})}$. The generally poor zircon yield and disproportionate "main" (vs. inherited) zircon population distribution may indicate that the host magma might not have (or just barely) reached zircon saturation conditions at the time of emplacement, yielding few contemporaneous zircons. 
Table 1. Summary of the weighted mean age and $\mathrm{Hf}$ isotopes of main and inheritance populations of analyzed zircon samples. Only populations with $n>2$ grains are shown, with an exception for the low-yield sample 17MLW028. Sample locations are provided in the accompanning digital data distributuin files.

\begin{tabular}{|c|c|c|c|c|c|c|}
\hline \multirow{2}{*}{ Sample } & \multirow{2}{*}{ Comments } & \multirow{2}{*}{$\begin{array}{c}{ }^{238} \mathrm{U} /{ }^{206} \mathrm{~Pb} \\
\text { best age [Ma] }\end{array}$} & \multicolumn{2}{|c|}{ Measured } & \multicolumn{2}{|c|}{ Age corrected (T) } \\
\hline & & & ${ }^{176} \mathrm{Hf} /{ }^{177} \mathrm{Hf}$ & $\varepsilon H f$ & ${ }^{176} \mathrm{Hf} /{ }^{177} \mathrm{Hf}(\mathrm{T})$ & $\varepsilon H f(T)$ \\
\hline 17AW017 & $\begin{array}{l}\text { main }(n=19) \\
\text { inheritance }(n=4) \\
\text { inheritance }(n=2)\end{array}$ & $\begin{array}{l}355.0 \pm 4.5 \\
404.8 \pm 27.5 \\
1238.4 \pm 45.0\end{array}$ & $\begin{array}{l}0.282027 \pm 0.000016 \\
0.281965 \pm 0.000096 \\
0.281906 \pm 0.002109\end{array}$ & $\begin{array}{l}-26.35 \pm 0.57 \\
-28.54 \pm 3.39 \\
-30.63 \pm 74.58\end{array}$ & $\begin{array}{l}0.282015 \\
0.281951 \\
0.281869\end{array}$ & $\begin{array}{l}-21.75 \\
-22.86 \\
-6.35\end{array}$ \\
\hline 17JEA001 & $\begin{array}{l}\text { main }(n=7) \\
\text { inheritance }(n=6) \\
\text { inheritance }(n=6)\end{array}$ & $\begin{array}{l}370.6 \pm 9.6 \\
1852.8 \pm 77.0 \\
2497.6 \pm 173.6\end{array}$ & $\begin{array}{l}0.281961 \pm 0.000025 \\
0.281469 \pm 0.000234 \\
0.281258 \pm 0.000028\end{array}$ & $\begin{array}{l}-28.68 \pm 0.88 \\
-46.08 \pm 8.28 \\
-53.54 \pm 0.99\end{array}$ & $\begin{array}{l}0.281952 \\
0.281457 \\
0.28123\end{array}$ & $\begin{array}{l}-23.57 \\
-6.43 \\
-1.00\end{array}$ \\
\hline 17ET057 & $(n=20)$ & $70.3 \pm 0.5$ & $0.282784 \pm 0.000034$ & $0.42 \pm 1.20$ & 0.282780 & -1.23 \\
\hline 17MLW060 & $(n=17)$ & $67.7 \pm 0.9$ & $0.282773 \pm 0.000036$ & $0.04 \pm 1.27$ & 0.282772 & -1.56 \\
\hline 17AW009 & $\begin{array}{l}\text { main }(n=15) \\
\text { Inheritance }(n=2) \\
\text { inheritance }(n=6)\end{array}$ & $\begin{array}{l}70.64 \pm 0.9 \\
111.1 \pm 9.0 \\
318.5 \pm 35.2\end{array}$ & $\begin{array}{l}0.282753 \pm 0.00003 \\
0.282584 \pm 0.000423 \\
0.282417 \pm 0.000175\end{array}$ & $\begin{array}{l}-0.67 \pm 1.06 \\
-6.65 \pm 14.96 \\
-12.55 \pm 6.19\end{array}$ & $\begin{array}{l}0.282751 \\
0.282581 \\
0.282408\end{array}$ & $\begin{array}{l}-2.22 \\
-7.33 \\
-8.65\end{array}$ \\
\hline 17MLW028 & $\begin{array}{l}\text { main? }(n=1) \\
\text { metamorphic }(n=1) \\
\text { inheritance }(n=4) \\
\text { inheritance }(n=4)\end{array}$ & $\begin{array}{l}71.5 \pm 3 \\
131 \pm 5.6 \\
267.9 \pm 22.8 \\
372.7 \pm 55.8\end{array}$ & $\begin{array}{l}0.28298 \pm 0.00017 \\
0.282736 \pm 0.000072 \\
0.282531 \pm 0.000508 \\
0.282185 \pm 0.000215\end{array}$ & $\begin{array}{l}7.7 \pm 6.01 \\
-1.27 \pm 2.55 \\
-8.52 \pm 17.97 \\
-20.76 \pm 7.60\end{array}$ & $\begin{array}{l}0.282977 \\
0.282736 \\
0.282526 \\
0.282177\end{array}$ & $\begin{array}{l}5.78 \\
-1.38 \\
-5.65 \\
-15.61\end{array}$ \\
\hline
\end{tabular}



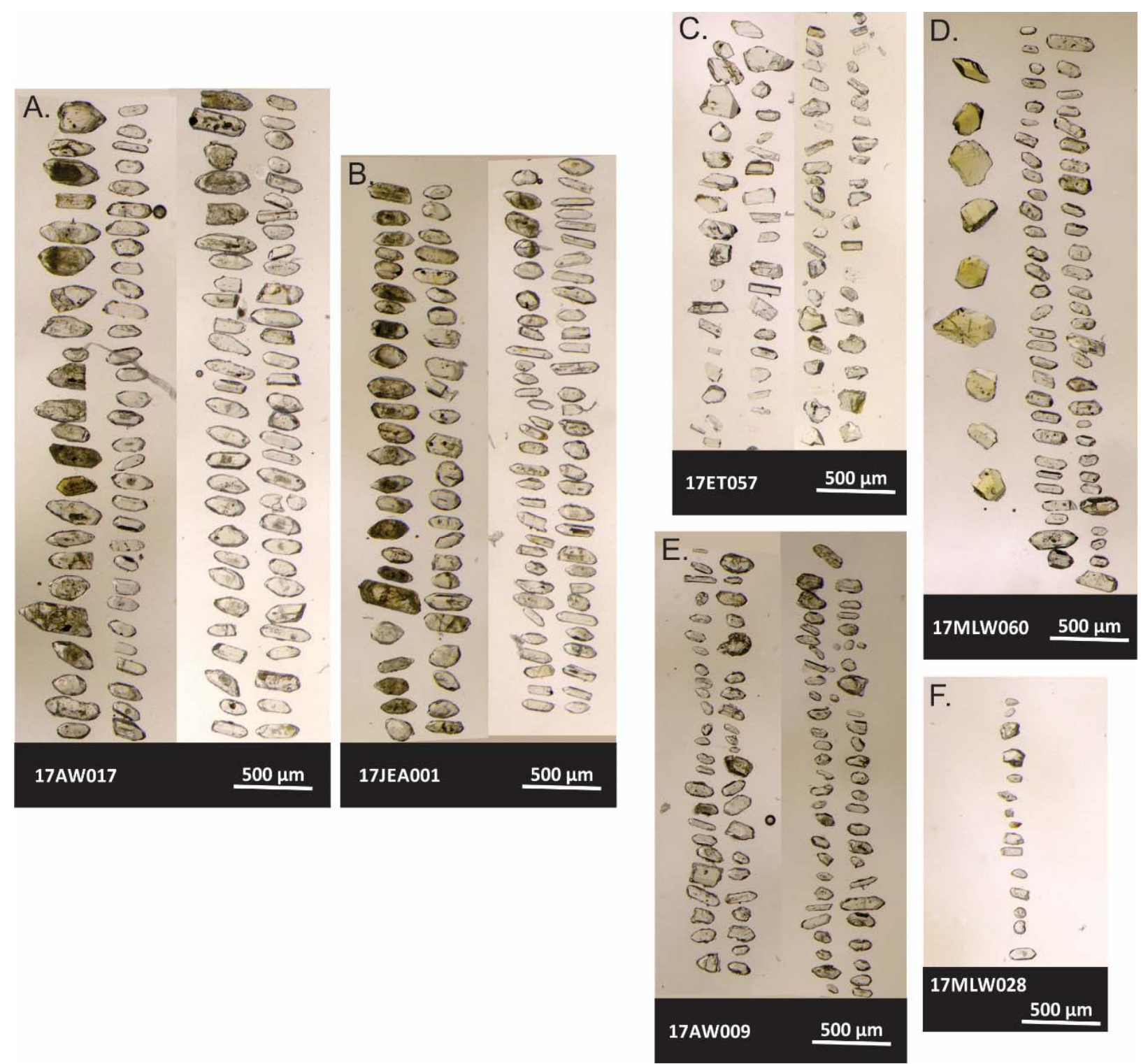

Figure 1. Photomicrographs of analyzed zircon grains from Lake George orthogneiss samples (A and B; 17 AW017 and 17JEA001, respectively), Pika diorite and andesite (C and D; $17 E T 057$ and 17MLW060, respectively), Taurus hornblende-feldspar porphyry (E; 17AW009), and VABM Lode andesite (F; 17MLW028). Left-most column of yellow grains for Pika sample in D are titanite, which were not analyzed in this session. 


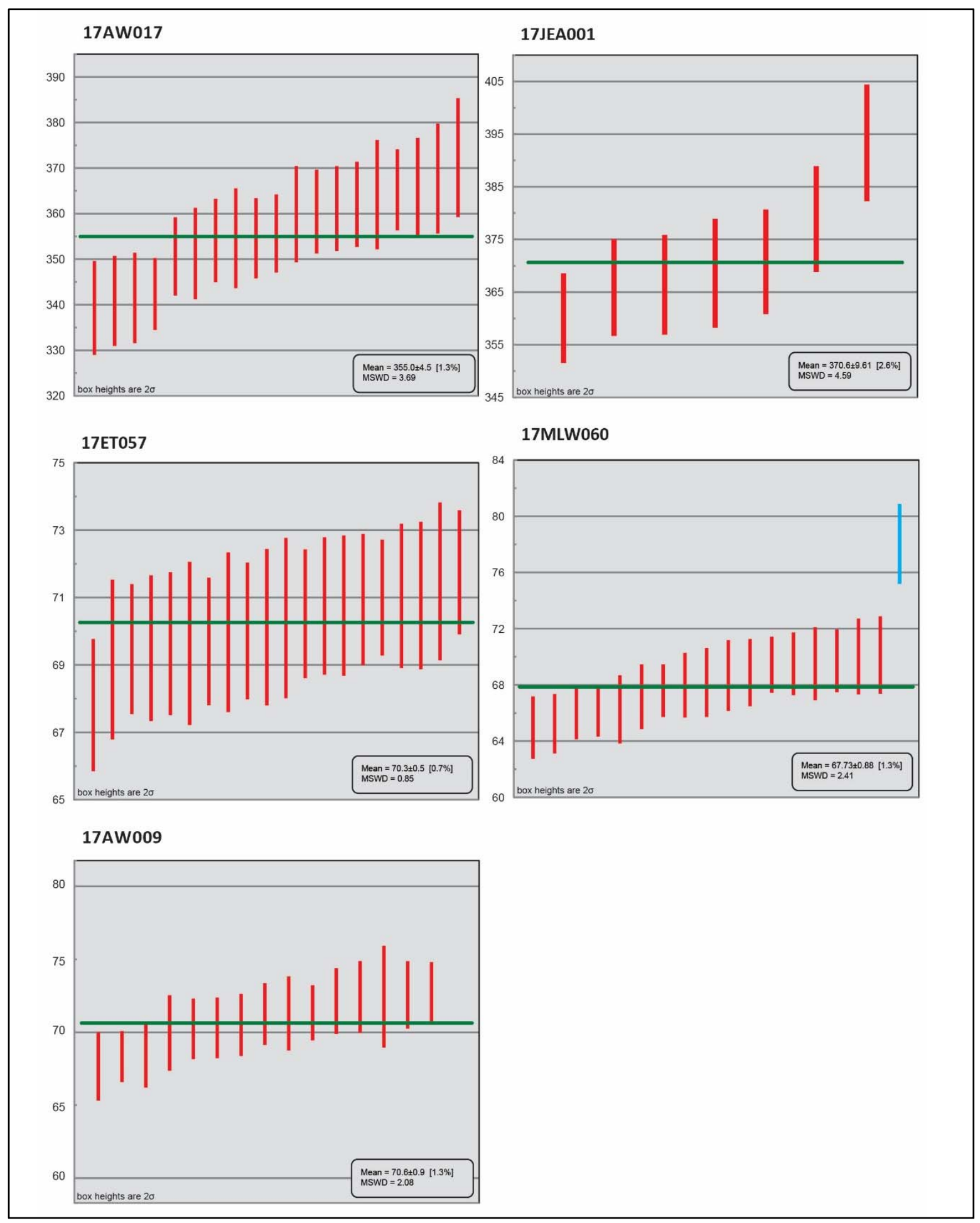

Figure 2. Plots of measured zircon U-Pb ages for main populations only. Sample $17 \mathrm{MLW} 028$ is not shown here because the crystallization suite is represented by a single grain. Red bars indicate zircon ages, at $2 \sigma$ bar height, that contribute to weighted means. Blue bars indicate zircon analyses that were excluded from the weighted mean (that is, omitted as statistical outliers). 


\section{ACKNOWLEDGMENTS}

The isotopic analyses in this report were funded through a cooperative partnership with the U.S. Geological Survey and the DGGS.

The Northeast Tanacross project was funded by Alaska State General Funds.

Any use of trade, firm, or product names is for descriptive purposes only and does not imply endorsement by the U.S. Government.

\section{REFERENCES CITED}

Blichert-Toft, Janne, and Albarède, Francis, 1997, The Lu-Hf isotope geochemistry of chondrites and the evolution of the mantle-crust system: Earth and Planetary Science Letters, v. 148, no. 1, p. 243-258. http://doi.org/10.1016/S0012-821X(97)00040-X

Dusel-Bacon, Cynthia, Hopkins, M.J., Mortensen, J.K., Dashevsky, S.S., Bressler, J.R., and Day, W.C., 2006, Paleozoic tectonic and metallogenic evolution of the pericratonic rocks of east-central Alaska and adjacent Yukon: in Colpron, Maurice, and Nelson J.L., eds., Paleozoic Evolution and Metallogeny of Pericratonic Terranes at the Ancient Pacific Margin of North America, Canadian and Alaskan Cordillera: Geological Association of Canada, Special Paper 45, p. 25-74.

Dusel-Bacon, Cynthia, Aleinikoff, J.N., Day, W.C., and Mortensen J.K., 2015, Mesozoic magmatism and timing of epigenetic $\mathrm{Pb}-\mathrm{Zn}$ - $\mathrm{Ag}$ mineralization in the western Fortymile mining district, east-central Alaska: Zircon U-Pb geochronology, whole-rock geochemistry, and Pb isotopes: Geosphere, v. 11, no. 3, p. 786-822. http://doi:10.1130/GES01092.1

Ferry, J.M., and Watson, E.B., 2007, New thermodynamic models and revised calibrations for the Ti-inzircon and Zr-in-rutile thermometers: Contributions to Mineralogy and Petrology, v. 154, no. 4, p. 429-437. http://doi.org/10.1007/s00410-007-0201-0

Foster, H.L., 1970, Reconnaissance geologic map of the Tanacross quadrangle, Alaska: U.S. Geological Survey Miscellaneous Geologic Investigations Map 593, 1 sheet, scale 1:250,000.

Griffin, W.L., Pearson, N.J., and Belousova, E.A., 2000, The Hf isotope composition of cratonic mantleLAM-MC-ICPMS analysis of zircon megacrysts in kimberlites: Geochimica et Cosmochimica Acta, v. 64, no. 1, p. 133-147. http://doi.org/10.1016/s0016-7037(99)00343-9

Kylander-Clark, A.R.C., Hacker, B.R., and Cottle, J.M., 2013, Laser-ablation split-stream ICP petrochronology: Chemical Geology, v. 345, p. 1-14. http://doi:10.1016/j.chemgeo.2013.02.019

Ludwig, K.R., 2012, User's manual for Isoplot 3.75, A geochronological toolkit for Microsoft Excel: Berkeley Geochronology Centre Special Publication no. 5 (rev. January 30, 2012), Berkeley, CA, USA.

Naibert, T.J., Benowitz, J.A., Wypych, Alicja, Sicard, K.R., and Twelker, Evan, $2018,{ }^{40} \mathrm{Ar} /{ }^{39} \mathrm{Ar}$ data from the Tanacross D-1 and D-2, Big Delta B-4 and B-5, and Mount Hayes A-6 quadrangles, Alaska: Alaska Division of Geological \& Geophysical Surveys Raw Data File 2018-3, p. 15 p.

Paton, Chad, Hellstrom, J.C., Paul, Bence, Woodhead, J.D., and Hergt, J.M., 2011, Iolite-Freeware for the visualization and processing of mass spectrometer data: Journal of Analytical Atomic Spectrometry, v. 26, p. 2,508-2,518. http://doi.org/10.1039/C1JA10172B 
Paton, Chad, Woodhead, J.D., Hellstrom, J.C., Hergt, J.M., Greig, Alan, and Maas, Roland, 2010, Improved laser ablation $\mathrm{U}-\mathrm{Pb}$ zircon geochronology through robust downhole fractionation correction: Geochemistry, Geophysics, Geosystems, v. 11, no. 3, Q0AA06. http://doi.org/10.1029/2009GC002618 Scherer, E.E., Münker, Carsten, and Mezger, Klaus, 2001, Calibration of the Lutetium-Hafnium clock: Science, v. 293, no. 5530, p. 683-687. http://doi.org/10.1126/science.1061372

Wilson, F.H., Hults, C.P., Mull, C.G., and Karl, S.M., 2015, Geologic map of Alaska: U.S. Geological Survey Scientific Investigations Map 3340, 197 p., 2 sheets, scale 1:1,584,000.

Woodhead, J.D., and Hergt, J.M., 2005, A preliminary appraisal of seven natural zircon reference materials for in situ Hf isotope determination: Geostandards and Geoanalytical Research, v. 29, no. 2, p. 183-195. http://doi.org/10.1111/j.1751-908X.2005.tb00891.x 